\title{
Optimasi Pengaruh Ekstrak Etanol 70 \% Bebas dan Tidak Bebas Alkaloid Daun Justicia gendarussa Burm. F terhadap Enzim Reverse Transcriptase HIV in vitro
}

\author{
Bambang Prayogo ${ }^{1}$, Prihartini Widiyanti ${ }^{2}$, Hafrizal Riza ${ }^{3}$ \\ ${ }^{1}$ Fakultas Farmasi, Universitas Airlangga \\ ${ }^{2}$ Fakultas MIPA, Universitas Airlangga \\ ${ }^{3}$ Program Studi Farmasi, Fakultas Kedokteran Universitas Tanjungpura
}

\begin{abstract}
Abstrak
Latar Belakang :Ekstrak etanol 70\% daun Justicia gendarussa Burm.f, bebas dan tidak bebas alkaloid dipercaya memiliki aktivitas inhibisi yang kuat terhadap enzim Reverse Transcriptase HIV, sebagai upaya menemukan solusi dalam menghadapi prevalensi HIV AIDS yang masih tinggi dengan kendala pengobatan HIV AIDS seperti efeks samping dan resistensi. Metode : Kedua jenis ekstrak diujikan secara in vitro menggunakan teknik Elisa dan dianalisa kandungan kimia yang Gendarusin A yang memiliki efek antiHIV menggunakan kromatografi cair kinerja tinggi. Hasil : Hasil uji Elisa diperoleh persen penghambatan berturut-turut sebesar , 254,2, 254,2, 235,6 dan 279,7 untuk konsentrasi 5 ppm, 10 ppm, 15 ppm dan 20 ppm ekstrak bebas alkaloid dan sebesar169,0, 164,0, 130,5 dan 369,5 untuk konsentrasi 5 ppm, 10 ppm, 15 ppm dan 20 ppm ekstrak tidak bebas alkaloid. Hasil kandungan kimia diperoleh Gendarusin A pada ekstrak bebas bebas alkaloid pada waktu retensi 8,402 menit dan ekstrak tidak bebas alkaloid pada waktu retensi 8,381. Kesimpulan : Justicia gendarussa Burm.f dapat menjadi sumber yang bermanfaat untuk isolasi dan pengembangan inhibitor baru antiHIV.
\end{abstract}

Kata kunci : Justicia gandarussa, ekstrak $70 \%$ etanol bebas dan tidak bebas alkaloid, reverse transcriptase, anti-HIV

Background : It was believed that $70 \%$ ethanol extract of leaves of Justicia gendarussa Burm.f, free and not free alkaloid, has a strong inhibitory activity against HIV reverse transcriptase enzyme, as an effort to find a solution in the face of HIV AIDS prevalence is still high with problem of HIV-AIDS treatment such as side effects and resistances. Method :Both types of extracts tested in vitro using Elisa technique and analyzed chemical content of Gendarusin A as antiHIV using high performance liquid chromatography. Result : Elisa test results obtained percent inhibition, respectively for 254.2 , $254.2,235.6$ and 279.7 for the concentration of $5 \mathrm{ppm}, 10 \mathrm{ppm}, 15 \mathrm{ppm}$ and $20 \mathrm{ppm}$ of free alkaloids extract and $169,0,164.0,130.5$ and 369.5 for the concentration of $5 \mathrm{ppm}, 10 \mathrm{ppm}, 15$ ppm and $20 \mathrm{ppm}$ are not free alkaloid extract. The results high performance liquid chromatography obtained Gendarusin A in the free alkaloid - extract at retention time 8.402 minutes and not free alkaloid extract at retention time 8.381. Conclusion : Justicia gendarussa Burm.f can be a useful source for the isolation and development of new inhibitors antiHIV .

Keyword : Justicia gandarussa, free and non free alkaloid of ekstract $70 \%$ ethanol extract , reverse transcriptase, anti-HIV

Jurnal Kesehatan Khatulistiwa. Volume 1 Nomor 2. April 2015 
PENDAHULUAN

Penyakit

HIV-AIDS

merupakan masalah global dan

penyakit paling mematikan di dunia.

Menurut laporan global WHO jumlah

kematian akibat AIDS di dunia pada

tahun 2009 mencapai 1,8 juta jiwa

(WHO, 2009). Sedangkan berdasarkan

data dari Kementerian Kesehatan RI, meskipun total kasus HIV dan AIDS

secara nasional menurun dari tahun

2011 sebanyak 21.031 dan 4.162

menjadi 9.883 dan 2.224 ditahun 2012

namun angka ini masih tergolong

tinggi (Kemenkes RI, 2012). Disisi

pengobatan, upaya medik dalam

pelayanan pengobatan HIV AIDS

masih menghadapi beberapa kendala.

Permasalahan seperti penggunaan

antiretroviral dimana dosis dan jenis

sangat dibatasi efek samping dari obat

antiretroviral. Toksisitas dan efek samping sangat mempengaruhi

kepatuhan pasien terhadap

antiretroviral. Selain itu penggunaan

antiretroviral dewasa ini mengalami

resistensi yang menyebabkan

kegagalan terapi (Flexner, 2007).

Salah satu strategi

penanggulangan HIV dan AIDS dapat

dilakukan dengan program penelitian

obat tradisional dari bahan alam yang

memiliki aktivitas anti HIV AIDS.

Penelitian obat tradisional diarahkan

untuk mencari bukti ilmiah tentang

obat tradisional tersebut (KPA, 2007).

Bahan alam masih memegang peranan

yang besar sebagai material awal

dalam penemuan obat baru (Feher and

Schmidt, 2003). Berdasarkan laporan

yang dipublikasikan tahun 2007,

bahwa terdapat 974 molekul senyawa

yang $63 \%$ berasal dari alam atau

derivat semisintetik yang berasal dari 
bahan alam (Newman and Cragg, 2007).

Enzim reverse transcriptase memegang peranan penting pada siklus hidup HIV karena transkripsi balik merupakan tahap awal replikasi virus di dalam sel host. Semua protein dan enzim yang memegang peranan penting pada pembentukan virus baru tidak dibawa oleh virus namun memanfaatkan enzim dan protein dalam sel host (Casiday and Frey, 2001). Sedangkan enzim reverse transcriptase bersama dengan enzim integrase berasal dari virus yang masuk pada sel host pada tahap fusi (Pommier, et al, 2005). Karena itu pengembangan obat yang bekerja pada enzim reverse transcriptase akan langsung menghambat proses siklus berikutnya mulai dari transkripsi balik RNA virus menjadi DNA, penggabungan DNA virus pada DNA sel host, replikasi inti hingga pembentukan protein virus. Penghambatan pada tahap sesudah transkripsi masih memungkinkan menetapnya infeksi dalam sel host karena DNA virus dapat menetap lama bersama dengan DNA sel host. Karena itu penghambatan pada enzim reverse transcriptase dapat menurunkan infeksi virus HIV (Casiday and Frey, 2001).

Saat ini sedang dikembangkan suatu obat anti HIV yang berasal dari tanaman obat yaitu Justicia gendarussa Burm.f. Penelitian yang telah dilakukan di antaranya menguji pengaruh ekstrak heksan, metanol dan etanol tanaman obat Justicia gandarussa Burm.f terhadap virus HIV in vitro dan diperoleh ekstrak metanol dan etanol $70 \%$ bebas alkaloid memberikan hasil penurunan jumlah 
virus (Yuliyangkara, 2010). Bagian herba Justicia gendarussa Burm.f menunjukkan aktivitas inhibisi enzim reverse transcriptase analog substrat in vitro (Woradulayapinij, et al, 2005). Senyawa isolat flavonoid apigenin murni menunjukkan penghambatan aktivitas enzim reverse transcriptase HIV sebagai analog substrat dan enzim protease $\mathrm{HIV}$ in vitro (Yeon-Ju, et al, 2009). Kandungan utama ekstrak etanol $70 \%$ Justicia gendarussa Burm.f adalah senyawa apigenin. Beberapa kandungan senyawa ini baik kompenen utama atau komponen minor dapat memberikan efek sinergis sebagai anti HIV melalui mekanisme yang sama ataupun berbeda (Gilbert and Alves, 2003). Karena itu pada penelitian ini dilakukan uji penghambatan aktivitas enzim Reverse Transcriptase HIV menggunakan ekstrak etanol $70 \%$ bebas dan tidak bebas alkaloid.

\section{METODOLOGI PENELITIAN}

Bahan

Daun Justicia gendarussa Burm.f diperoleh dari tanaman budidaya di daerah Trawas, Mojokerto, Jawa Timur. Roche RT Activity Kit diperoleh dari PT. Roche, Jerman. Bahan untuk ekstraks, uji alkaloid dan kandungan kimia yaitu etanol $70 \%$, diklorometan, metanol, heksan, aquades, asam sitrat, kertas saring, pereaksi dragendorf, Silika gel GF 254. 
Reader, seperangkat alat HPLC : Untuk memastikan bebas alkaloid Agilent1100, Kolom reverse phase maka kelompok pertama diuji bebas Nova-pak® C18 dengan ukuran alkaloid menggunakan Kromatografi $3,9 \times 150 \mathrm{~mm}$. Lapis Tipis dengan fase diam Silika

\section{Tempat pelaksanaan penelitian}

Penelitian dilakukan di dua laboratorium yaitu laboratorium Farmakognosi, Fakultas Farmasi, Universitas Airlangga dan laboratorium Institut Penyakit Tropis, Universitas Airlangga.

\section{Rancangan Penelitian}

\section{Simplisia daun Justicia}

gendarussa Burm.f dibagi menjadi dua kelompok sampel. Kelompok pertama diasamkan untuk membebaskan alkaloid dan kelompok kedua tidak diasamkan. Kemudian kedua kelompok sampel dimaserasi dengan etanol $70 \%$ dan kemudian dipekatkan.
Gel GF 254 dan fase gerak diklorometan : metanol, $9: 1$ dengan peraksi semprot Dragendorf. Kedua macam sampel diujikan aktivitasnya dalam inhibisi aktivitas enzim Reverse Transcriptase HIV menggunakan Elisa dan ditentukan jenis inhibitornya. Kedua sampel juga dianalisa kandungan kimia untuk mengetahui kadar Gendarusin A yang berdasarkan penelitian sebelumnya bahwa isolat apigenin memiliki aktivitas inhibisi Reverse Transkriptase HIV. Kondisi yang digunakan dalam HPLC yaitu eluen metanol : air (30:70), aliran 1 $\mathrm{ml} / \mathrm{menit}$, stop time 25 menit, panjang gelombang $254 \mathrm{~nm}$. 


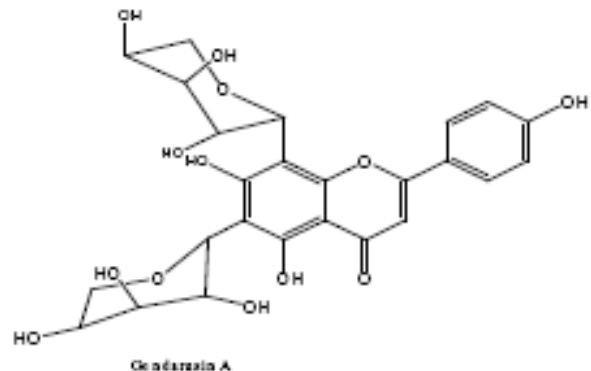

Gambar 1. Struktur gendarusin A

\section{HASIL DAN PEMBAHASAN}

Pada penelitian, dilakukan uji untuk mengetahui aktivitas inhibisi ekstrak etanol $70 \% \quad$ Justicia gendarussa Burm.f terhadap enzim Reverse Transcriptase HIV dan perbedaan perlakuan pengasaman untuk melihat pengaruh alkaloid pada inhibisi enzim Reverse Transcriptase HIV. Ekstraksi dilakukan dengan maserasi etanol $70 \%$ karena penelitian sebelumnya menunjukkan ekstrak ini mampu menurunkan jumlah kultur virus HIV in vitro.

Untuk memastikan kelompok pertama bebas alkaloid maka dilakukan uji bebas alkaloid dan diperoleh hasil kelompok pertama bebas alkaloid seperti ditunjukkan pada gambar 2, noda A yaitu ekstrak bebas alkaloid tidak menunjukkan noda jingga merah seperti pada noda B dan noda $\mathrm{C}$.
Gambar 2. Hasil uji bebas alkaloid, A (noda ekstrak bebas alkaloid), B(noda ekstrak tidak bebas alkaloid), $\mathrm{C}$ (pembanding Piper nigrum $\mathrm{L}$ ). 
Untuk uji inhibisi aktivitas enzim Reverse Transcriptase HIV diperoleh dengan menggunakan rumus

$$
\% \text { Inhibisi }=\left[\frac{A_{0}-A_{1}}{A_{0}}\right] \times 100 \%
$$

Keterangan :

$\mathrm{A} 0=$ Absorbansi blanko

A1= Absorbansi sampel

Tabel 1. Persen penghambatan ekstrak etanol $70 \%$ bebas dan tidak bebas alkaloid daun Justicia gendarussa Burm.f terhadap aktivitas enzim Reverse Transcriptase HIV.

\begin{tabular}{|c|c|c|}
\hline Sampel & Konsentrasi & \%Inhibisi \\
\hline \multirow[t]{4}{*}{ A } & $20 \mathrm{ppm}$ & 279,7 \\
\hline & $15 \mathrm{ppm}$ & 235,6 \\
\hline & $10 \mathrm{ppm}$ & 254,2 \\
\hline & $5 \mathrm{ppm}$ & 254,2 \\
\hline \multirow[t]{4}{*}{ B } & $20 \mathrm{ppm}$ & 369,5 \\
\hline & $15 \mathrm{ppm}$ & 130,5 \\
\hline & $10 \mathrm{ppm}$ & 164,0 \\
\hline & $5 \mathrm{ppm}$ & 169,0 \\
\hline $\mathrm{K}+$ & $100 \mu \mathrm{g} / \mathrm{ml}$ & 83 \\
\hline $\mathrm{K}-$ & - & - \\
\hline \multirow{2}{*}{\multicolumn{3}{|c|}{$\begin{array}{c}\text { Keterangan: A : Ekstrak tidak bebas alkaloid } \\
\text { B : Ekstrak bebas alkaloid }\end{array}$}} \\
\hline & & \\
\hline \multicolumn{3}{|c|}{$\begin{array}{c}\mathrm{K}+\cdot \mathrm{Kontrol} \text { positif (Doksorubisin } \\
100 \mathrm{ug} / \mathrm{ml} \text { ) }\end{array}$} \\
\hline \multicolumn{3}{|c|}{ K- : Kontrol negatif (larutan uji } \\
\hline
\end{tabular}

Tabel 1 menunjukkan kedua ekstrak memiliki aktivitas penghambatan enzim Reverse Transcriptase HIV yang ditunjukkan dengan persen penghambatan.

Untuk analisa kandungan kimia Gendarusin A diperoleh pada waktu retensi 8,402 menit untuk ekstrak bebas alkaloid dan waktu retensi 8 , 381 menit dibandingkan dengan standar Gendarusin A 9,6 ppm dengan waktu retensi 8,590 menit.

\section{KESIMPULAN}

Dari hasil penelitian ini dapat disimpulkan bahwa ekstrak etanol 70\% daun Justicia gendarussa Burm.f bebas dan tidak bebas alkaloid memiliki aktivitas penghambatan enzim Reverse Transcriptase HIV. 


\section{DAFTAR PUSTAKA}

1. World Health Organization, Golbal Summary of The HIV AIDS Epidemic, on December2009,(online),(http://www.who.i nt/hiv/data/2009 global_summary.png,dia kses 10 November 2011), 2009.

2. Kementerian Kesehatan Republik Indonesia, Laporan Situasi Perkembangan HIV\&AIDS di Indonesia sampai dengan Juni 2011, (online), (http://www.aidsindonesia.or.id/download/ LT2Menkes2011.pdf, diakses 13 November 2011), 2011.

3. Flexner C, HIV Drug Development: The Next 25 Years, Natural Review Drug Discovery, Vol 6, pp.959-66, 2007.

4. Komisi Penanggulangan AIDS, Strategi Nasional Penanggulangan HIV dan AIDS 2007-2010, (online), (http://www.undp.or.id/programme/propoor/The $\% 20$ National $\% 20$ HIV $\% 20 \& \% 20$ AIDS\%20Strategy\%2020072010\%20\%28I ndonesia\%29.pdf, diakses 3 November 2011), 2007.

5. Feher M, and Schmidt J.M, Property Distributions: Differences Between Drugs, Natural Products, And Molecules From Combinatorial Chemistry, Journal of Chemical Information and Computer Science, Vol 43, pp.218-27, 2003.

6. Newman D.J, and Cragg G.M, Natural Products As Sources Of New Drugs Over The Last 25 Years, Journal of Natural Product,.Vol 70, pp.461-77, 2007.

7. Casiday, R., and Frey, R., Drug Strategies to Target HIV: Enzyme Kinetics and Enzyme Inhibitors, Department of Chemistry, Washington University, 2001.

8. Pommier Y, Johnson A.A, and Marchand C, Integrase Inhibitors to Treat HIV/AIDS, Nature Review: Drug Discovery, Vol 4, pp.236-48, 2005.

9. Yuliangkara B, Prajogo B.EW, dan Widiyanti P, Pengaruh Ekstrak Heksan, Metanol, dan Etanol Tanaman Obat Justicia gendarussa Burm.f terhadap Virus HIV In Vitro, Skripsi, Fakultas Farmasi, Universitas Airlangga, Surabaya, 2010.

10.Woradulayapinij W, Soonthornchareonnon $\mathrm{N}$, and Wiwat $\mathrm{C}$, In vitro HIV Type 1
Reverse transcriptase Inhibitory Activity of Thai Medicinal Plants and Canna indica L. rizhomes, Journal of Ethnopharmacology, Vol 101, pp.84-9, 2005.

11. Yeon-Ju K, Hyun-Jeong O, Hyo-Min A, Ho-Jung Kang, Jung-Hyun K, and YoungHwan K, Flavonoids as Potential Inhibitors of Retroviral Enzymes, Journal of the Korean Society for Applied Biological Chemistry, Vol 52, pp.321-6, 2009.

12.Gilbert B, and Alves L.F, Synergy in Plant Medicine, Current Medical Chemistry, Vol 10, pp.13-20, 2003. 